\title{
Data report: clay mineral assemblages in the upper Shikoku Basin, results from IODP Expedition 333, Sites $\mathrm{C} 0011$ and $\mathrm{C} 0012^{1}$
}

\author{
Michael B. Underwood ${ }^{2}$ and Junhua Guo ${ }^{3}$
}

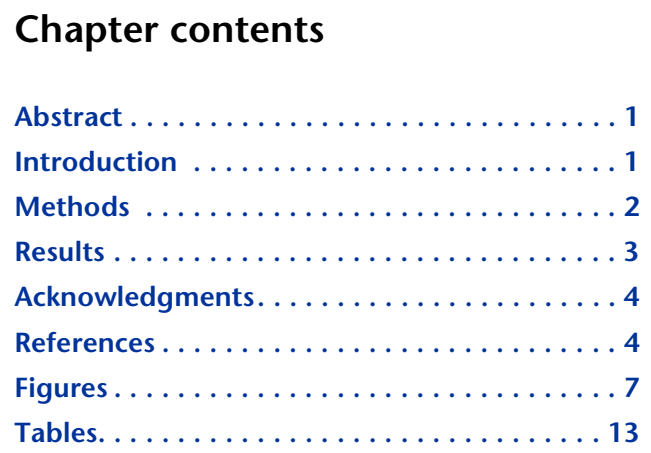

${ }^{1}$ Underwood, M.B., and Guo, J., 2017. Data report: clay mineral assemblages in the upper Shikoku Basin, results from IODP Expedition 333, Sites C0011 and C0012. In Henry, P., Kanamatsu, T., Moe, K., and the Expedition 333 Scientists, Proceedings of the Integrated Ocean Drilling Program, 333: Tokyo (Integrated Ocean Drilling Program Management International, Inc.). doi:10.2204/iodp.proc.333.205.2017

${ }^{2}$ Department of Earth and Environmental Science, New Mexico Institute of Mining and Technology, Socorro NM, USA. UnderwoodM@missouri.edu ${ }^{3}$ Department of Geological Sciences, California State University Bakersfield, Bakersfield CA, USA.

\section{Abstract}

This report summarizes the results of X-ray diffraction analyses of core samples from Integrated Ocean Drilling Program (IODP) Sites C0011 and C0012, offshore southwest Japan. We analyzed 211 specimens $(<2 \mu \mathrm{m}$ size fraction) recovered during IODP Expedition 333. Most of those samples come from the uppermost hemipelagic/pyroclastic facies (Unit I) of the Shikoku Basin, with a limited number from the volcanic turbidite facies (Unit II) and the pelagic clay facies (Unit V). Minerals of the smectite group are generally the most abundant. At Site C0011, the amount of smectite in the clay-size fraction of Unit I averages $40.8 \mathrm{wt} \%$ (standard deviation $=11.5$ ) and increases downsection. Proportions of illite and chlorite average 36.4 and $15.5 \mathrm{wt} \%$, respectively. Average contents of kaolinite and quartz are 3.6 and $3.7 \mathrm{wt} \%$, respectively. At Site C0012 (Unit I), the amount of smectite averages $50.0 \mathrm{wt} \%$ (standard deviation $=13.5$ ) and increases downsection. Averages for the other minerals in the clay-size fraction are illite $=31.8$ $\mathrm{wt} \%$, chlorite $=10.1 \mathrm{wt} \%$, kaolinite $=5.5 \mathrm{wt} \%$, and quartz $=2.6$ $\mathrm{wt} \%$. Most values of illite/smectite expandability fall between $60 \%$ and $70 \%$, and there are no systematic changes downsection. Values of the illite crystallinity index are generally consistent with detrital sources that were exposed to anchizone metamorphic conditions.

\section{Introduction}

The Nankai Trough Seismogenic Zone Experiment (NanTroSEIZE) comprises several sampling expeditions that crossed the subduction system offshore southwest Japan (Ashi et al., 2009; Screaton et al., 2009; Tobin et al., 2009, 2015; Underwood et al., 2010; Strasser et al., 2014; see the "Expedition 333 summary" chapter [Expedition 333 Scientists, 2012a]). Integrated Ocean Drilling Program (IODP) Expeditions 322 and 333 concentrated on coring the inputs of sediment to the subduction zone (see Underwood et al., 2010; also see the "Expedition 333 summary" chapter [Expedition 333 Scientists, 2012a]). IODP Sites C0011 and C0012 are located in the Shikoku Basin (Fig. F1), on the northwest flank and at the summit of a basement high known as Kashinosaki Knoll 
(Ike et al., 2008). The stratigraphic column for those sites is divided into five major facies units (Fig. F2). The section above the basement high is condensed, but all of the facies units can be correlated between sites.

The dominant lithology within Unit I of the Shikoku Basin (hemipelagic/pyroclastic facies) is clayey silt (hemipelagic mud to mudstone) with abundant interbeds of silt- to sand-size volcanic ash. At Site C0011, the depositional age of Unit I ranges from Quaternary to late Miocene ( 7.6 Ma), based on integration of calcareous nannofossil events, paleomagnetic datums, and tephrachronology (see the "Site C0011" chapter [Expedition 333 Scientists, 2012b]). The base of Unit I at Site C0012 is approximately $7.8 \mathrm{Ma}$ in age using a similar integrated agedepth model (see the "Site C0012" chapter [Expedition 333 Scientists, 2012c]).

Because of time limitations during Expedition 322, coring at Site C0011 started 340 meters below seafloor (mbsf) rather than at the mudline. The lithologic characterization of Unit I was based initially on logging-while-drilling results (see Underwood et al., 2010); those results were not verified by coring until Expedition 333 (see the "Expedition 333 summary" chapter [Expedition 333 Scientists, 2012a]). Coring of the upper intervals at Site C0012 was likewise deferred until Expedition 333. Previous studies in the Nankai-Shikoku region showed that hemipelagic mud(stones) change in composition largely as function of depositional age (e.g., Chamley, 1980; Chamley et al., 1986; Underwood et al., 1993a, 1993b; Steurer and Underwood, 2003; Underwood and Steurer, 2003; Guo and Underwood, 2012; Underwood and Guo, 2013). Hemipelagic sedimentation during the Miocene was dominated by expandable clay minerals (smectite group), whereas the proportions of detrital illite and chlorite increased steadily through the Pliocene and Quaternary. It is important to demonstrate whether or not sediments at Sites C0011 and C0012 conform to that temporal trend because the diagenetic and hydration states of subducting Shikoku Basin strata influence fluid production and hydrogeological properties within and beneath the Nankai accretionary prism (e.g., Saffer et al., 2008). This report documents the results of X-ray diffraction (XRD) analyses of 211 samples recovered during Expedition 333. Underwood and Guo (2013) presented complementary XRD data from the deeper Expedition 322 samples.

\section{Methods}

\section{Sample preparation}

All of the samples analyzed in this study came from "clusters" that included companion specimens for shipboard bulk powder XRD, X-ray fluorescence, and carbon-carbonate; those shipboard XRD scans provided estimates of the relative abundance of total clay minerals, quartz, feldspar, and calcite (see the "Site C0011" and "Site C0012" chapters [Expedition 333 Scientists, 2012b, 2012c]).

We isolated the clay-size $(<2 \mu \mathrm{m})$ fractions by air-drying and gentle hand-crushing of the mudstone with mortar and pestle, after which specimens were immersed in $3 \% \mathrm{H}_{2} \mathrm{O}_{2}$ for at least $24 \mathrm{~h}$ to digest organic matter. We added $\sim 250 \mathrm{~mL}$ of Na-hexametaphosphate solution (concentration of $4 \mathrm{~g} / 1000 \mathrm{~mL}$ distilled $\mathrm{H}_{2} \mathrm{O}$ ) and used an ultrasonic bath for several minutes to promote disaggregation and deflocculation. Washing consisted of two passes through a centrifuge (8200 rpm for $25 \mathrm{~min}$; $\sim 6000 \mathrm{~g}$ ) with resuspension in distilled deionized water after each pass. Each sample was resuspended by vigorous shaking and 2 min exposure to an ultrasonic cell probe immediately before centrifugation $(1000 \mathrm{rpm}$ for 2.4 min; $\sim 320 \mathrm{~g})$. The clay-size splits $(<2 \mu \mathrm{m}$ equivalent settling diameter) were mounted on glass discs following the filter-peel method (Moore and Reynolds, 1989) using $0.45 \mu \mathrm{m}$ filter membranes. Clay aggregates were saturated with ethylene glycol in a closed vapor chamber heated to $60^{\circ} \mathrm{C}$ for at least $24 \mathrm{~h}$ prior to XRD analysis.

\section{X-ray diffraction}

Clay-size specimens from Expedition 333 were analyzed using two X-ray diffractometers. When the project began, the XRD laboratory at the University of Missouri was equipped with a Scintag Pad V X-ray diffractometer with $\mathrm{CuK} \alpha$ radiation $(1.54 \AA)$ and $\mathrm{Ni}$ filter. Scans of oriented clay aggregates were run at $40 \mathrm{kV}$ and $30 \mathrm{~mA}$ over a scanning range of $3^{\circ}$ to $26.5^{\circ} 2 \theta$, a rate of $1^{\circ} 2 \theta / \mathrm{min}$, and a step size of $0.01^{\circ} 2 \theta$. Slits were $0.5 \mathrm{~mm}$ (divergence) and $0.2 \mathrm{~mm}$ (receiving). The Department of Geological Sciences shut down that facility before our study was finished. The remaining samples were analyzed at the New Mexico Bureau of Geology and Mineral Resources, using a Panalytical X'Pert Pro diffractometer with $\mathrm{Cu}$ anode. Those continuous scans were com- 
pleted with generator settings of $45 \mathrm{kV}$ and $40 \mathrm{~mA}$ over an angular range of $3^{\circ}$ to $26.5^{\circ} 2 \theta$, scan step time of $1.6 \mathrm{~s}$, and step size of $0.01^{\circ} 2 \theta$. Slits were fixed at $1.0 \mathrm{~mm}$ (divergence) and $0.1 \mathrm{~mm}$ (receiving), and the sample holder was set to spinning. The digital data were processed using MacDiff software (version 4.2.5) to draw a baseline of intensity, smooth counts, correct peak positions offset by misalignment of the detector (using the quartz [100] peak at $20.95^{\circ} 20$; dvalue $=4.24 \AA$ ), calculate integrated peak area (total counts), and measure peak width at half height $\left(\Delta^{\circ} 2 \theta\right)$.

\section{Calculations of mineral abundance}

Given the unusually large number of samples throughout the NanTroSEIZE project, our priority has been to obtain semiquantitative accuracy with optimal efficiency. To accomplish that for the claysize fraction, we first analyzed standard mineral mixtures and computed a matrix of normalization factors using singular value decomposition (SVD). Underwood et al. (2003) provided a full description of the standards and a thorough analysis of the error. Average errors using this method are 3.9\% for smectite, $1.0 \%$ for illite, $1.9 \%$ for chlorite, and $1.6 \%$ for quartz. Because of differences in X-ray tubes and instruments, we needed to solve for three sets of normalization factors (Table T1) and then use them during computations. Figure F3 shows representative examples of the integrated areas of a broad smectite (001) peak centered at $\sim 5.3^{\circ} 2 \theta(\mathrm{d}$-value $=16.5 \AA)$, the illite (001) peak at $\sim 8.9^{\circ} 2 \theta(\mathrm{d}$-value $=9.9 \AA)$, the composite chlorite $(002)+$ kaolinite $(001)$ peak at $12.5^{\circ} 2 \theta$ (d-value $=7.06 \AA)$, and the quartz $(100)$ peak at $20.85^{\circ} 2 \theta$ (d-value $=4.26 \AA$ ). For simplicity, the term "smectite" is used here as a label for mixtures of several possible detrital and authigenic minerals within the smectite group, plus small amounts of smectiterich illite/smectite (I/S) mixed-layer clay. Figure F3 also provides an example of the computation array for SVD normalization factors.

The chlorite (002) and kaolinite (001) peaks overlap almost completely, so a refined version of the Biscaye (1964) method was used to discriminate kaolinite (002) from chlorite (004), as documented by Guo and Underwood (2011). Chlorite is the dominant mineral, so the relevant power-function regression is

$$
\% \text { chlorite }=100 \times(\mathrm{PA} / \mathrm{TA})^{1.433} \text {, }
$$

where PA $=2 \times$ half-peak area for chlorite $(004)$ and $\mathrm{TA}=$ total peak area for composite chlorite $(004)+$ kaolinite (002). Analyses of standard mineral mixtures showed that the average error of accuracy for the chlorite/kaolinite ratio is $2.6 \%$ (Guo and Under- wood, 2011). We computed individual mineral percentages using that ratio and the SVD weight percent of undifferentiated chlorite (002) + kaolinite (001).

To calculate the abundance of individual clay minerals in the bulk sediment (e.g., smectite), we multiplied each relative weight percent value among the clay minerals (where smectite + illite + chlorite + kaolinite $=100 \%$ ) by the weight percent of total clay minerals within the bulk powder (where total clay minerals + quartz + feldspar + calcite $=100 \%$ ), as determined by shipboard XRD analyses of collocated specimens (see the "Site C0011" and "Site C0012" chapters, [Expedition 333 Scientists, 2012b, 2012c]). To facilitate direct comparisons with other published data sets from the region, we also report the weighted peak area percentages for smectite, illite, and undifferentiated chlorite + kaolinite using Biscaye (1965) weighting factors $(1 \times$ smectite, $4 \times$ illite, and $2 \times$ chlorite + kaolinite). Errors of accuracy using that method can be substantially greater $( \pm 10 \%$ or more) as compared to the errors using SVD factors (Underwood et al., 2003).

The saddle/peak method of Rettke (1981) was used to calculate percent expandability for assemblages of smectite and smectite-rich I/S mixed-layer clay. This method is sensitive to the proportions of discrete illite (I) versus I/S mixed-layer clay; the curve for 1:1 mixtures of I and I/S provides the best match for the range of Nankai specimens. The values of expandability should not be overinterpreted, however, because each represents a collective response to natural mixtures of detrital smectite, authigenic smectite, and smectite-rich detrital mixed-layer I/S. We also report values of illite crystallinity (Kübler) index as peak width at half height $\left(\Delta^{\circ} 2 \theta\right)$ for the (001) reflection; the illite peak typically narrows as levels of thermal maturity increase.

\section{Results}

Tables T2 and T3 show the peak area values (total counts) for common minerals in the clay-size fraction, segregated by lithologic unit. Tables T2 and T3 also include the values of mineral abundance ( $\mathrm{wt} \%$ ) calculated with SVD normalization factors and weighted peak area percentages using Biscaye (1965) factors. Those SVD values are rounded to the nearest $1 \mathrm{wt} \%$ in acknowledgment of the statistical disadvantages of using three sets of SVD normalization factors and two diffractometers.

\section{Site $\mathrm{C} 0011$}

The relative abundance of clay-size smectite within the hemipelagic/pyroclastic facies (Unit I) ranges from 12 to $68 \mathrm{wt} \%$ (Fig. F4) with a mean value ( $\mu$ ) of 
$40.8 \mathrm{wt} \%$ and a standard deviation $(s)$ of 11.5 . The depth distribution defines a general trend of steadily increasing smectite content downsection. The amount of illite in the clay-size fraction ranges from 23 to $49 \mathrm{wt} \%(\mu=36.4 \mathrm{wt} \% ; s=5.7)$, and we recognize a general trend of decreasing illite content downsection. Percentages of chlorite range from 5 to $29 \mathrm{wt} \%(\mu=15.5 \mathrm{wt} \% ; s=4.8)$. Percentages of claysize kaolinite and quartz average $3.6 \mathrm{wt} \%(s=3.2)$ and $3.7 \mathrm{wt} \%(s=4.0)$, respectively.

Samples from the upper intervals of Unit II (volcanic turbidite facies) are similar in clay composition to those near the base of Unit I (Fig. F4). Percentages of clay-size smectite range from 37 to $97 \mathrm{wt} \%$, and illite varies from 3 to $43 \mathrm{wt} \%$. Interested readers should refer to Underwood and Guo (2013) to see continuations of those trends farther downsection.

Figure F5 illustrates how the abundance of smectite within the bulk sediment changes as a function of depth. Within Unit I, the values range from 7 to 48 wt $\%(\mu=27.1 \mathrm{wt} \% ; s=8.4)$. Comparable values within lithologic Unit II range from 29 to $55 \mathrm{wt} \%$, continuing the general trend of increasing percentages of smectite with increasing depth and age.

Illite crystallinity (Kübler) index values within Unit I range from $0.84 \Delta^{\circ} 2 \theta$ to $0.27 \Delta^{\circ} 2 \theta$ with an average of $0.43 \Delta^{\circ} 2 \theta$. We consider such values as basic indicators of generic conditions within detrital source areas. As a qualitative frame of reference, the boundary between advanced diagenesis and anchizone metamorphism is set at $0.52 \Delta^{\circ} 2 \theta$, and the achizone/epizone boundary (incipient greenschist facies) coincides with $0.32 \Delta^{\circ} 2 \theta$ (Warr and Mählmann, 2015). We see no systematic changes in illite crystallinity with depth. Similarly, the expandability of smectite and I/S mixed-layer clay ranges from $49 \%$ to $91 \%(\mu=66 \%)$, with no systematic changes as a function of depth.

\section{Site $\mathrm{C} 0012$}

The relative abundance of clay-size smectite within Unit I ranges from 22 to $69 \mathrm{wt} \%$ (Fig. F6). As at Site C0011, results define a general trend in which smectite content increases downsection, although with more scatter and a higher mean $(\mu=50.0 \mathrm{wt} \% ; s=$ 13.5). Values for illite range from 18 to $46 \mathrm{wt} \%(\mu=$ $31.8 \mathrm{wt} \% ; s=6.6$ ), with a similar trend of decreasing concentrations downsection. Chlorite is consistently subordinate, ranging from 2 to $19 \mathrm{wt} \%(\mu=10.1$ wt $\% ; s=5.4)$, whereas clay-size kaolinite $(\mu=5.5$ wt $\% ; s=4.1)$ and quartz $(\mu=2.6 \mathrm{wt} \% ; s=2.9)$ remain consistently low. Calculated values of smectite in bulk sediment (Fig. F7) range from 6 to $55 \mathrm{wt} \%(\mu$ $=32.7 \mathrm{wt} \% ; s=11.7$ ). Illite crystallinity (Kübler) index values range from $0.76 \Delta^{\circ} 2 \theta$ to $0.27 \Delta^{\circ} 2 \theta$ (Fig. F7) with an average of $0.38 \Delta^{\circ} 2 \theta$. The expandability of smectite plus I/S mixed-layer clay ranges from 52\% to $83 \%$ with an average value of $67 \%$.

The 11 samples that we analyzed from the upper intervals of Unit II (volcanic turbidite facies) are similar in clay composition to those near the base of Unit I (Figs. F6, F7). Percentages of clay-size smectite range from 42 to $75 \mathrm{wt} \%$, and illite varies from 20 to $35 \mathrm{wt} \%$ (see Underwood and Guo, 2013, for downhole continuations of those trends). We also obtained data from six samples from Unit $V$, which is the pelagic clay facies in depositional contact with uppermost basalt (Fig. F2). The ranges in composition for Unit V are smectite $=23-62 \mathrm{wt} \%$, illite $=20$ $50 \mathrm{wt} \%$, chlorite $=7-15 \mathrm{wt} \%$, kaolinite $=0 \mathrm{wt} \%$, and clay-size quartz $=11-31 \mathrm{wt} \%$ (Table T3). Several additional specimens from Unit $V$ failed to produce reliable clay-mineral peaks because of high concentrations of biogenic calcite.

\section{Acknowledgments}

This research used samples provided by the Integrated Ocean Drilling Program (IODP). We thank the Mantle Quest Japan drilling crew, Marine Works Japan laboratory technicians, and scientists aboard the $\mathrm{D} / \mathrm{V}$ Chikyu for their dedicated assistance during IODP Expedition 333. Funding was granted by the Consortium for Ocean Leadership, U.S. Science Support Program (task order T333B58) and the National Science Foundation (grant OCE-07518190). U. Shriniwar, N. Walla, and C. Song assisted with sample preparation. We thank an anonymous reviewer for their comments.

\section{References}

Ashi, J., Lallemant, S., Masago, H., and the Expedition 315 Scientists, 2009. Expedition 315 summary. In Kinoshita, M., Tobin, H., Ashi, J., Kimura, G., Lallemant, S., Screaton, E.J., Curewitz, D., Masago, H., Moe, K.T., and the Expedition 314/315/316 Scientists, Proceedings of the Integrated Ocean Drilling Program, 314/315/316: Washington, DC (Integrated Ocean Drilling Program Management International, Inc.). https://doi.org/10.2204/ iodp.proc.314315316.121.2009

Biscaye, P.E., 1964. Distinction between kaolinite and chlorite in recent sediments by X-ray diffraction. American Mineralogist, 49:1281-1289. http://www.minsocam.org/ammin/AM49/AM49_1281.pdf

Biscaye, P.E., 1965. Mineralogy and sedimentation of recent deep-sea clay in the Atlantic Ocean and adjacent seas and oceans. Geological Society of America Bulletin, 76(7):803-831. https://doi.org/10.1130/00167606(1965)76[803:MASORD]2.0.CO;2 
Chamley, H., 1980. Clay sedimentation and paleoenvironment in the Shikoku Basin since the middle Miocene (Deep Sea Drilling Project Leg 58, North Philippine Sea). In Klein, G. de V., Kobayashi, K., et al., Initial Reports of the Deep Sea Drilling Project, 58:

Washington, DC (U.S. Govt. Printing Office), 669-678. https://doi.org/10.2973/dsdp.proc.58.118.1980

Chamley, H., Cadet, J.-P., and Charvet, J., 1986. Nankai Trough and Japan Trench late Cenozoic paleoenvironments deduced from clay mineralogic data. In Kagami, H., Karig, D.E., Coulbourn, W.T., et al., Initial Reports of the Deep Sea Drilling Project, 87: Washington, DC (U.S. Govt. Printing Office), 633-641. https:// doi.org/10.2973/dsdp.proc.87.113.1986

Expedition 333 Scientists, 2012a. Expedition 333 summary. In Henry, P., Kanamatsu, T., Moe, K., and the Expedition 333 Scientists, Proceedings of the Integrated Ocean Drilling Program, 333: Tokyo (Integrated Ocean Drilling Program Management International, Inc.). https://doi.org/10.2204/iodp.proc.333.101.2012

Expedition 333 Scientists, 2012b. Site C0011. In Henry, P., Kanamatsu, T., Moe, K., and the Expedition 333 Scientists, Proceedings of the Integrated Ocean Drilling Program, 333: Tokyo (Integrated Ocean Drilling Program Management International, Inc.). https://doi.org/10.2204/ iodp.proc.333.104.2012

Expedition 333 Scientists, 2012c. Site C0012. In Henry, P., Kanamatsu, T., Moe, K., and the Expedition 333 Scientists, Proceedings of the Integrated Ocean Drilling Program, 333: Tokyo (Integrated Ocean Drilling Program Management International, Inc.). https://doi.org/10.2204/ iodp.proc.333.105.2012

Guo, J., and Underwood, M.B., 2011. Data report: refined method for calculating percentages of kaolinite and chlorite from X-ray diffraction data, with application to the Nankai margin of southwest Japan. In Kinoshita, M., Tobin, H., Ashi, J., Kimura, G., Lallemant, S., Screaton, E.J., Curewitz, D., Masago, H., Moe, K.T., and the Expedition 314/315/316 Scientists, Proceedings of the Integrated Ocean Drilling Program, 314/315/316: Washington, DC (Integrated Ocean Drilling Program Management International, Inc.). https://doi.org/10.2204/ iodp.proc.314315316.201.2011

Guo, J., and Underwood, M.B., 2012. Data report: clay mineral assemblages from the Nankai Trough accretionary prism and the Kumano Basin, IODP Expeditions 315 and 316, NanTroSEIZE Stage 1. In Kinoshita, M., Tobin, H., Ashi, J., Kimura, G., Lallemant, S., Screaton, E.J., Curewitz, D., Masago, H., Moe, K.T., and the Expedition 314/315/316 Scientists, Proceedings of the Integrated Ocean Drilling Program, 314/315/316: Washington, DC (Integrated Ocean Drilling Program Management International, Inc.). https://doi.org/10.2204/

iodp.proc.314315316.202.2012

Ike, T., Moore, G.F., Kuramoto, S., Park, J.-O., Kaneda, Y., and Taira, A., 2008. Tectonics and sedimentation around Kashinosaki Knoll: a subducting basement high in the eastern Nankai Trough. Island Arc, 17(3):358-375. https://doi.org/10.1111/j.1440-1738.2008.00625.x
Moore, D.M., and Reynolds, R.C., Jr., 1989. Sample preparation techniques for clay minerals. In Moore, D.M., and Reynolds, R.C., Jr. (Eds.), X-Ray Diffraction and the Identification and Analysis of Clay Minerals: New York (Oxford University Press), 179-201.

Rettke, R.C., 1981. Probable burial diagenetic and provenance effects on Dakota Group clay mineralogy, Denver Basin. Journal of Sedimentary Petrology, 51(2):541-551. https://doi.org/10.1306/212F7CCF-2B24-11D78648000102C1865D

Saffer, D.M., Underwood, M.B., and McKiernan, A.W., 2008. Evaluation of factors controlling smectite transformation and fluid production in subduction zones: application to the Nankai Trough. Island Arc, 17(2):208230. https://doi.org/10.1111/j.1440-

1738.2008.00614.x

Screaton, E.J., Kimura, G., Curewitz, D., and the Expedition 316 Scientists, 2009. Expedition 316 summary. In Kinoshita, M., Tobin, H., Ashi, J., Kimura, G., Lallemant, S., Screaton, E.J., Curewitz, D., Masago, H., Moe, K.T., and the Expedition 314/315/316 Scientists, Proceedings of the Integrated Ocean Drilling Program, 314/315/ 316: Washington, DC (Integrated Ocean Drilling Program Management International, Inc.). https:// doi.org/10.2204/iodp.proc.314315316.131.2009

Steurer, J.F., and Underwood, M.B., 2003. Clay mineralogy of mudstones from the Nankai Trough reference Sites 1173 and 1177 and frontal accretionary prism Site 1174. In Mikada, H., Moore, G.F., Taira, A., Becker, K., Moore, J.C., and Klaus, A. (Eds.), Proceedings of the Ocean Drilling Program, Scientific Results, 190/196: College Station, TX (Ocean Drilling Program), 1-37. https://doi.org/ 10.2973/odp.proc.sr.190196.211.2003

Strasser, M., Dugan, B., Kanagawa, K., Moore, G.F., Toczko, S., Maeda, L., Kido, Y., Moe, K.T., Sanada, Y., Esteban, L., Fabbri, O., Geersen, J., Hammerschmidt, S., Hayashi, H., Heirman, K., Hüpers, A., Jurado Rodriguez, M.J., Kameo, K., Kanamatsu, T., Kitajima, H., Masuda, H., Milliken, K., Mishra, R., Motoyama, I., Olcott, K., Oohashi, K., Pickering, K.T., Ramirez, S.G., Rashid, H., Sawyer, D., Schleicher, A., Shan, Y., Skarbek, R., Song, I., Takeshita, T., Toki, T., Tudge, J., Webb, S., Wilson, D.J., Wu, H.-Y., and Yamaguchi, A., 2014. Expedition 338 summary. In Strasser, M., Dugan, B., Kanagawa, K., Moore, G.F., Toczko, S., Maeda, L., and the Expedition 338 Scientists, Proceedings of the Integrated Ocean Drilling Program, 338: Yokohama (Integrated Ocean Drilling Program). https://doi.org/10.2204/iodp.proc.338.101.2014

Tobin, H., Hirose, T., Saffer, D., Toczko, S., Maeda, L., Kubo, Y., Boston, B., Broderick, A., Brown, K., Crespo-Blanc, A., Even, E., Fuchida, S., Fukuchi, R., Hammerschmidt, S., Henry, P., Josh, M., Jurado, M.J., Kitajima, H., Kitamura, M., Maia, A., Otsubo, M., Sample, J., Schleicher, A., Sone, H., Song, C., Valdez, R., Yamamoto, Y., Yang, K., Sanada, Y., Kido, Y., and Hamada, Y., 2015. Expedition 348 summary. In Tobin, H., Hirose, T., Saffer, D., Toczko, S., Maeda, L., Kubo, Y., and the Expedition 348 Scientists, Proceedings of the Integrated Ocean Drilling Program, 348: College Station, TX (Integrated Ocean Drill- 
ing Program). https://doi.org/10.2204/

iodp.proc.348.101.2015

Tobin, H., Kinoshita, M., Ashi, J., Lallemant, S., Kimura, G., Screaton, E.J., Moe, K.T., Masago, H., Curewitz, D., and the Expedition 314/315/316 Scientists, 2009. NanTroSEIZE Stage 1 expeditions: introduction and synthesis of key results. In Kinoshita, M., Tobin, H., Ashi, J., Kimura, G., Lallemant, S., Screaton, E.J., Curewitz, D., Masago, H., Moe, K.T., and the Expedition 314/315/316 Scientists, Proceedings of the Integrated Ocean Drilling Program, 314/315/316: Washington, DC (Integrated Ocean Drilling Program Management International, Inc.). https://doi.org/10.2204/ iodp.proc.314315316.101.2009

Underwood, M.B., Basu, N., Steurer, J., and Udas, S., 2003. Data report: normalization factors for semiquantitative $\mathrm{X}$-ray diffraction analysis, with application to DSDP Site 297, Shikoku Basin. In Mikada, H., Moore, G.F., Taira, A., Becker, K., Moore, J.C., and Klaus, A. (Eds.), Proceedings of the Ocean Drilling Program, Scientific Results, 190/ 196: College Station, TX (Ocean Drilling Program), 128. https://doi.org/10.2973/ odp.proc.sr.190196.203.2003

Underwood, M.B., and Guo, J., 2013. Data report: clay mineral assemblages in the Shikoku Basin, NanTroSEIZE subduction inputs, IODP Sites C0011 and C0012. In Saito, S., Underwood, M.B., Kubo, Y., and the Expedition 322 Scientists, Proceedings of the Integrated Ocean Drilling Program, 322: Tokyo (Integrated Ocean Drilling Program Management International, Inc.). https:// doi.org/10.2204/iodp.proc.322.202.2013

Underwood, M.B., Orr, R., Pickering, K., and Taira, A., 1993a. Provenance and dispersal patterns of sediments in the turbidite wedge of Nankai Trough. In Hill, I.A., Taira, A., Firth, J.V., et al., Proceedings of the Ocean Drilling Program, Scientific Results, 131: College Station, TX
(Ocean Drilling Program), 15-34. https://doi.org/ 10.2973/odp.proc.sr.131.105.1993

Underwood, M.B., Pickering, K., Gieskes, J.M., Kastner, M., and Orr, R., 1993b. Sediment geochemistry, clay mineralogy, and diagenesis: a synthesis of data from Leg 131, Nankai Trough. In Hill, I.A., Taira, A., Firth, J.V., et al., Proceedings of the Ocean Drilling Program, Scientific Results, 131: College Station, TX (Ocean Drilling Program), 343-363. https://doi.org/10.2973/ odp.proc.sr.131.137.1993

Underwood, M.B., Saito, S., Kubo, Y., and the Expedition 322 Scientists, 2010. Expedition 322 summary. In Saito, S., Underwood, M.B., Kubo, Y., and the Expedition 322 Scientists, Proceedings of the Integrated Ocean Drilling Program, 322: Tokyo (Integrated Ocean Drilling Program Management International, Inc.). https://doi.org/ 10.2204/iodp.proc.322.101.2010

Underwood, M.B., and Steurer, J.F., 2003. Composition and sources of clay from the trench slope and shallow accretionary prism of Nankai Trough. In Mikada, H., Moore, G.F., Taira, A., Becker, K., Moore, J.C., and Klaus, A. (Eds.), Proceedings of the Ocean Drilling Program, Scientific Results, 190/196: College Station, TX (Ocean Drilling Program), 1-28. https://doi.org/10.2973/ odp.proc.sr.190196.206.2003

Warr, L.N., and Mählmann, R.F., 2015. Recommendations for Kübler Index standardization. Clay Minerals, 50(3):283-286. https://doi.org/10.1180/clay$\min .2015 .050 .3 .02$

Initial receipt: 16 June 2016

Acceptance: 22 May 2017

Publication: 16 August 2017

MS 333-205 
Figure F1. Shikoku Basin study area with locations of Sites C0011 and C0012. White circles = locations of other NanTroSEIZE drill sites along the Kumano transect.

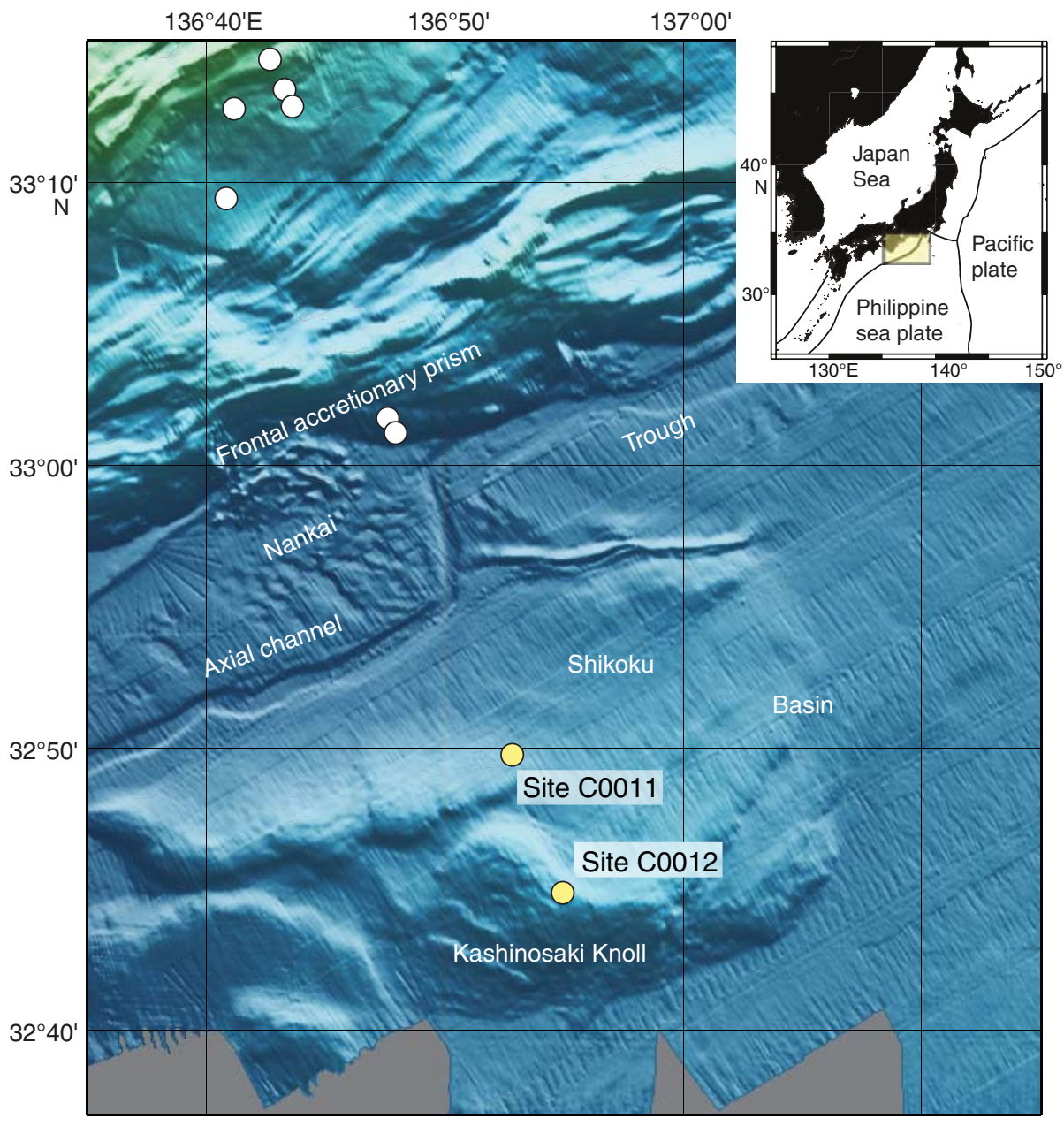


Figure F2. Seismic in-line section crossing the Shikoku Basin showing locations of Sites C0011 and C0012 (Underwood et al., 2010). Correlative facies units were defined by shipboard analyses of cores and logging-while-drilling data (see Underwood et al., 2010; see the "Expedition 333 summary" chapter [Expedition 333 Scientists, 2012a]). VE = vertical exaggeration.

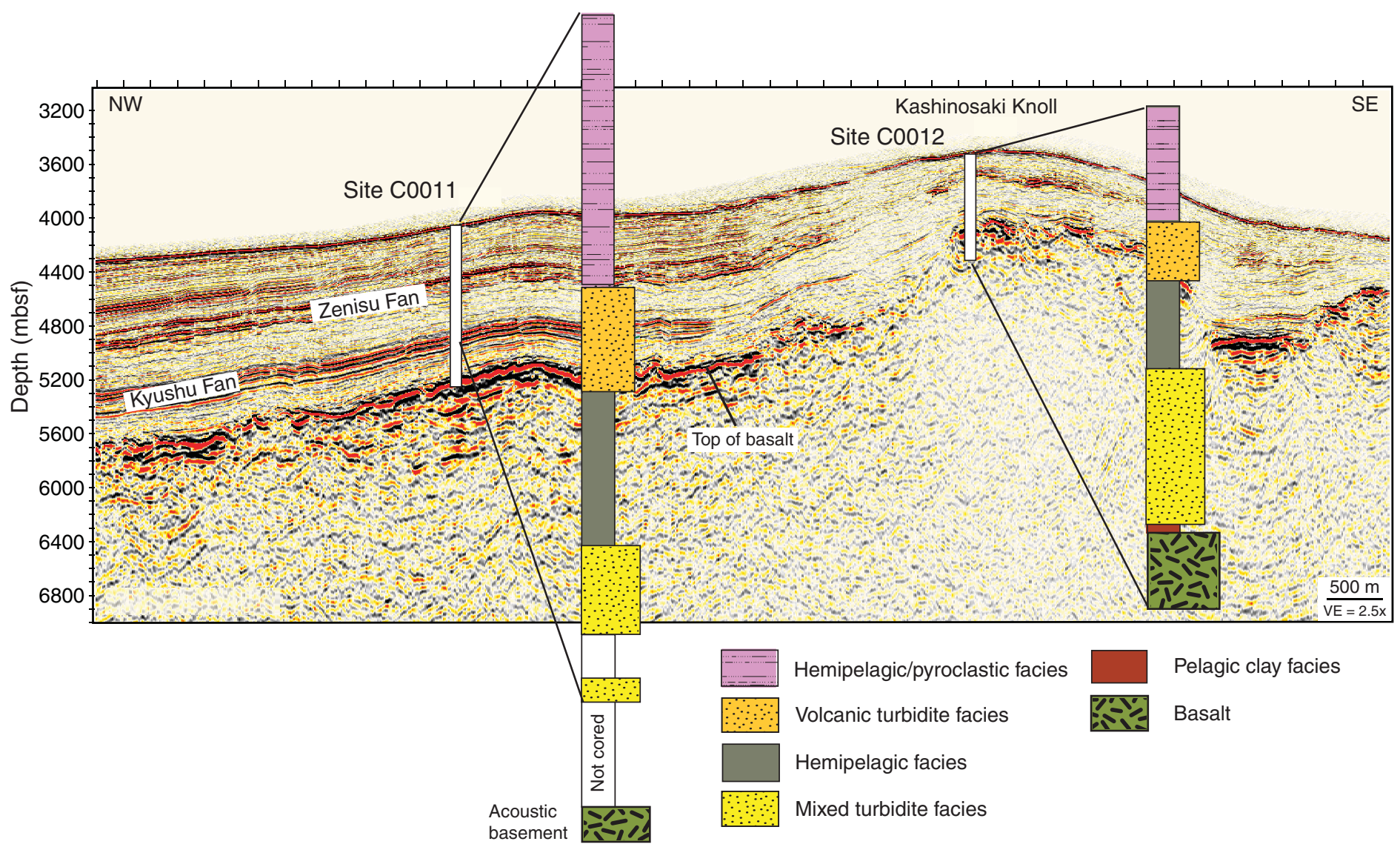


Figure F3. X-ray diffractograms of two representative clay-size specimens, Expedition 333. Values of integrated peak area (total counts) are shown above the diagnostic peaks. Also shown is an example of the computation array using SVD normalization factors from Set 2 (see Table T1). $S=$ smectite, I = illite, CK = chlorite + kaolinite, $\mathrm{Q}=$ quartz. $\mathrm{PA}=2 \times$ half-peak area for chlorite $(004), \mathrm{TA}=$ total peak area for composite chlorite (004) + kaolinite (002).
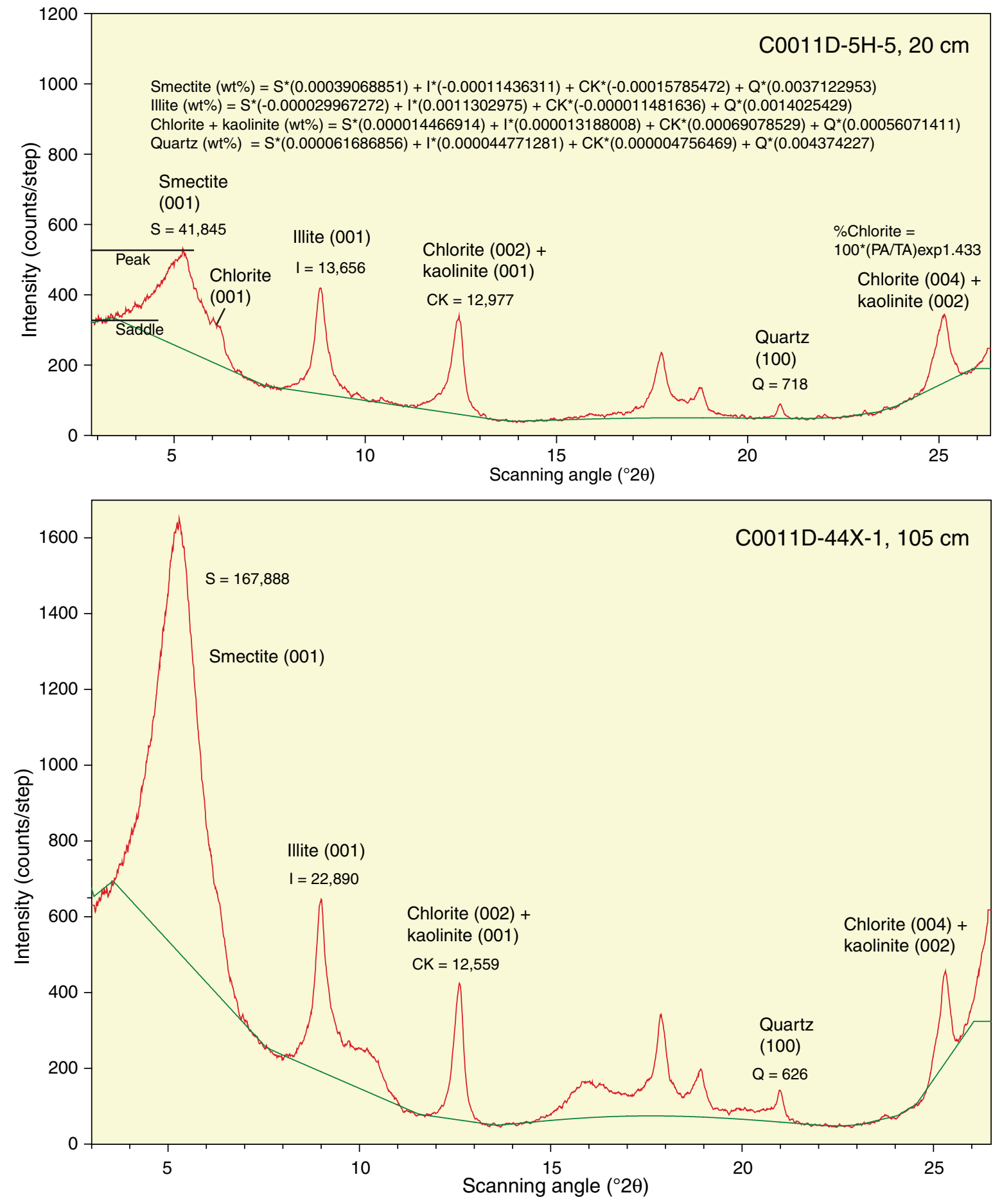
Figure F4. Calculated relative abundances of smectite, illite, chlorite, kaolinite, and quartz within the clay-size fraction of core samples, Site C0011. See Underwood and Guo (2013) for continuation of results from deeper stratigraphic intervals.

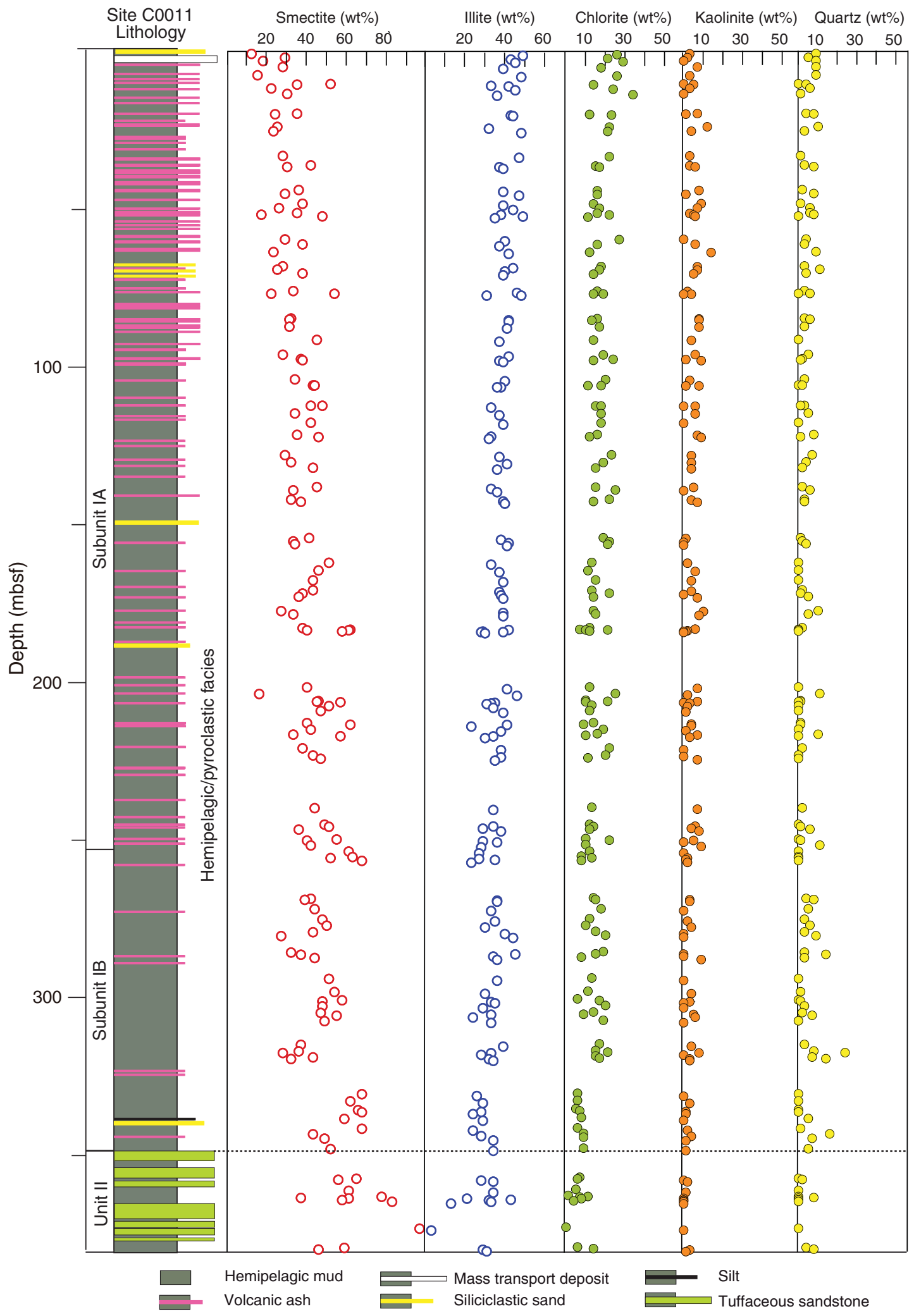


Figure F5. Values of total clay minerals in bulk sediment (see the "Site C0011" chapter [Expedition 333 Scientists, 2012b]), smectite in bulk sediment, illite/smectite (I/S) expandability, and illite crystallinity (Kübler) index within the clay-size fraction of core samples, Site C0011. Boundaries for anchizone and epizone metamorphism are from Warr and Mählmann (2015). See Underwood and Guo (2013) for continuation of results from deeper stratigraphic intervals.

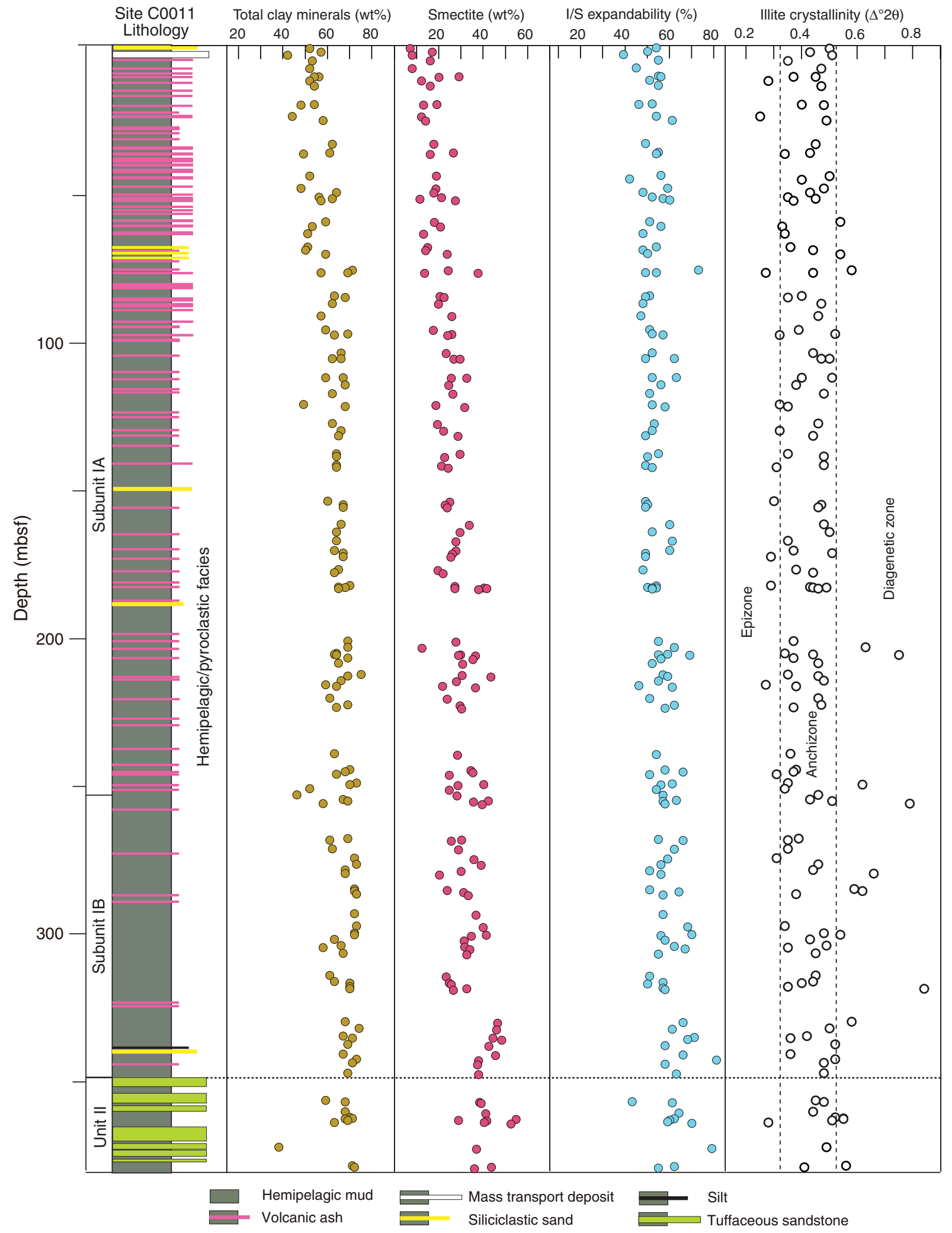


Figure F6. Calculated relative abundances of smectite, illite, chlorite, kaolinite, and quartz within the clay-size fraction of core samples, Site C0012 (see the "Site C0012" chapter [Expedition 333 Scientists, 2012c]). See Underwood and Guo (2013) for continuation of results from deeper stratigraphic intervals.

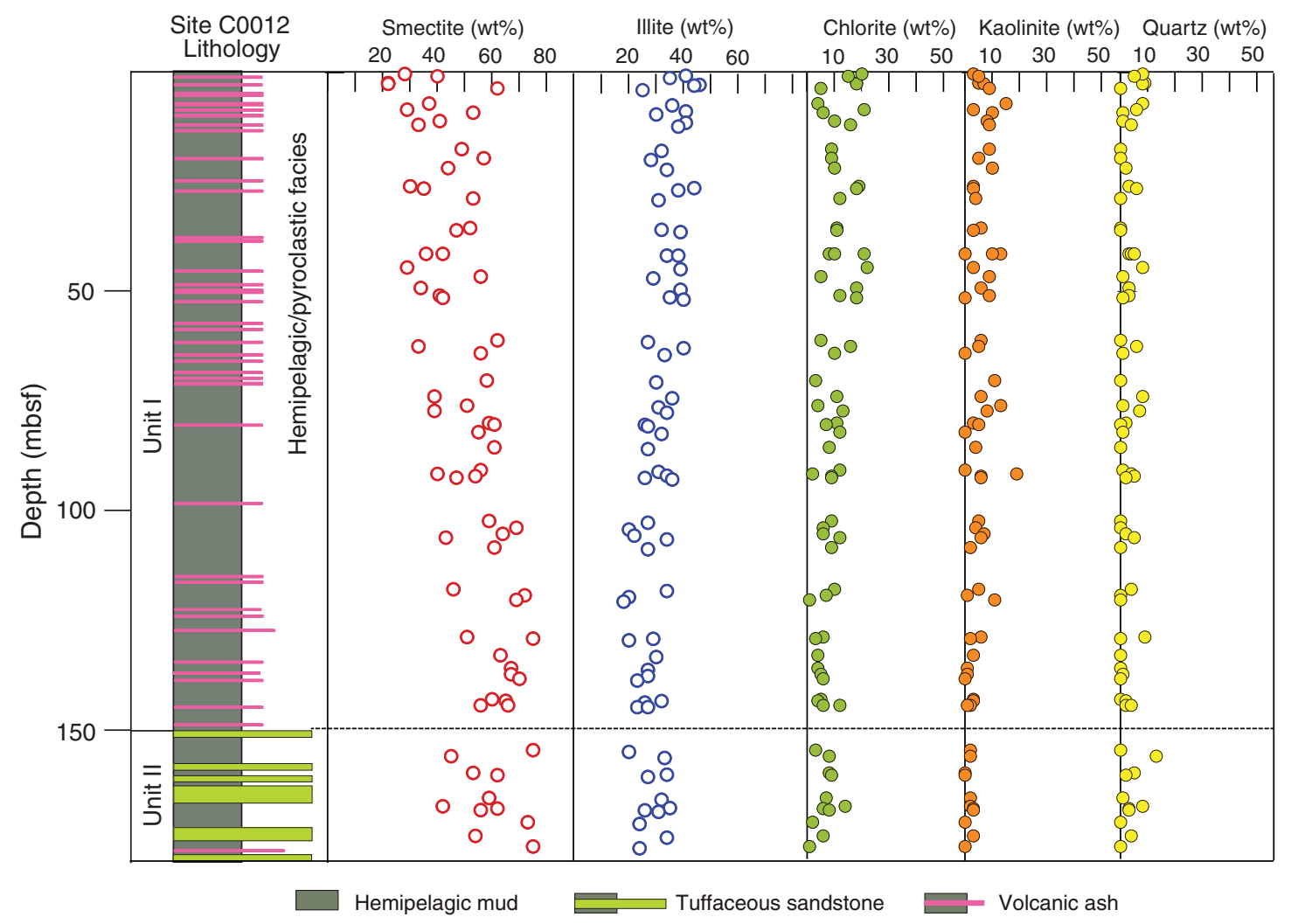


Figure F7. Values of total clay minerals in bulk sediment (see the "Site C0012" chapter [Expedition 333 Scientists, 2012c]), smectite in bulk sediment, illite/smectite (I/S) expandability, and illite crystallinity (Kübler) index within the clay-size fraction of core samples, Site C0012. Boundaries for anchizone and epizone metamorphism are from Warr and Mählmann (2015). See Underwood and Guo (2013) for continuation of results from deeper stratigraphic intervals.

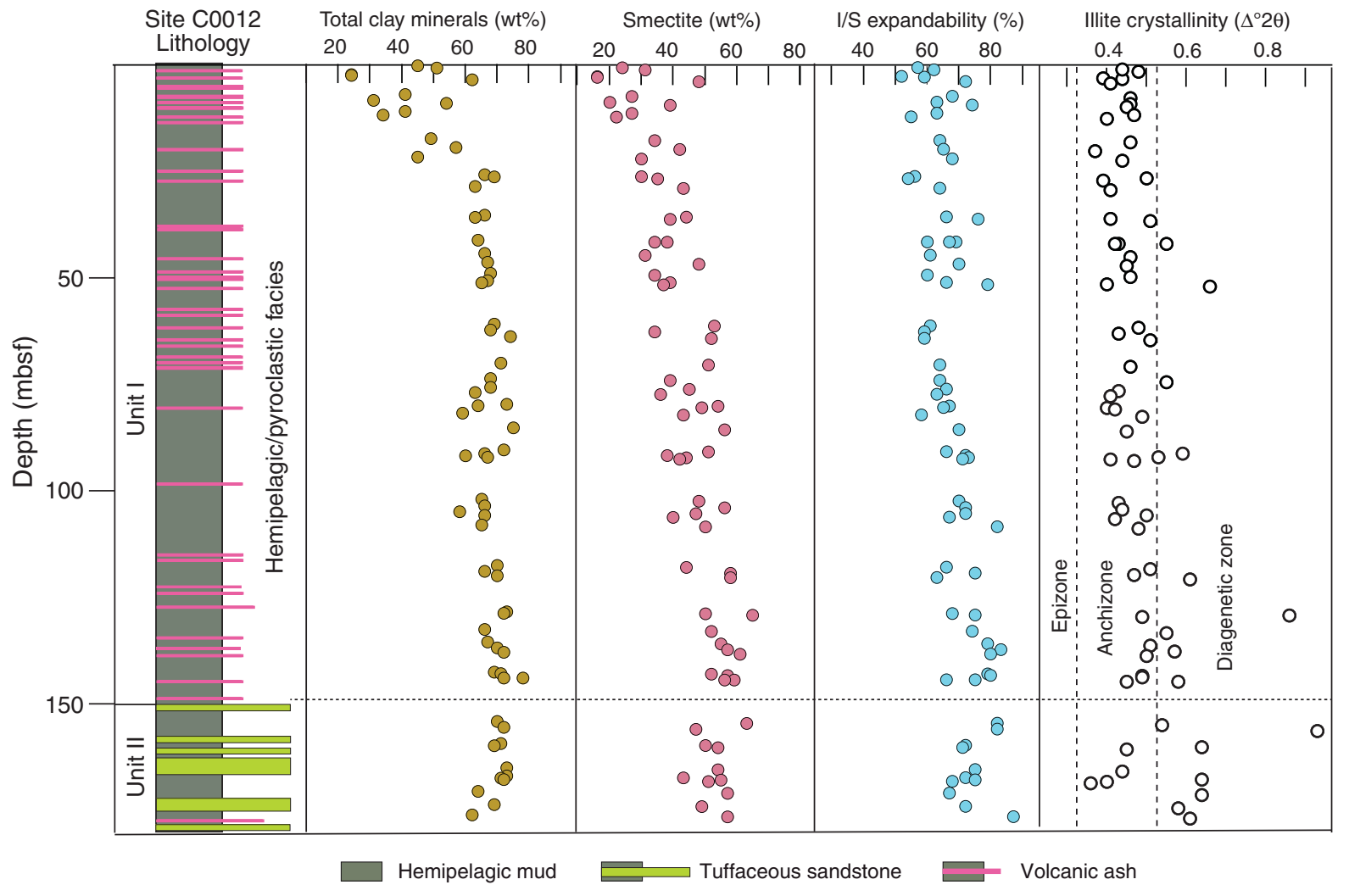

Table T1. Matrix of normalization factors used to calculate relative mineral abundances in clay-size aggregates, derived from singular value decomposition.

\begin{tabular}{lcccr}
\hline \multirow{2}{*}{$\begin{array}{c}\text { Influencing } \\
\text { mineral }\end{array}$} & Smectite & Illite & Chlorite & Quartz \\
\cline { 2 - 5 } & Set & & \\
\hline Set 1: University of Missouri & & & \\
Smectite & 0.0003739856 & -0.0000289946 & -0.0000343775 & -0.0000744212 \\
Illite & 0.0000427201 & 0.0012499784 & -0.0000283639 & 0.0000338385 \\
Chlorite & -0.0000676622 & -0.0000002008 & 0.0007697485 & 0.0000524088 \\
Quartz & 0.0024368789 & 0.0009231154 & 0.0008195109 & 0.0037061975 \\
Set 2: University of Missouri & & & \\
Smectite & 0.0003906885 & -0.0000299673 & -0.0000144669 & -0.0000616869 \\
Illite & -0.0001143631 & 0.0011302975 & 0.0000131880 & 0.0000447713 \\
Chlorite & -0.0001578547 & -0.0000114816 & 0.0006907853 & 0.0000047565 \\
Quartz & 0.0037122953 & 0.0014025429 & 0.0005607141 & 0.0043742270 \\
Set 3: New Mexico Bureau of Geology and Mineral Resources & \\
Smectite & 0.0007447529 & -0.0000319536 & -0.0000750672 & -0.0001566192 \\
Illite & 0.0000631147 & 0.0037866938 & 0.0000842230 & 0.0001176929 \\
Chlorite & -0.0003563606 & -0.0000673781 & 0.0025121504 & 0.0000522907 \\
Quartz & 0.0093573136 & 0.0036491468 & 0.0032755411 & 0.0148256450 \\
\hline \multicolumn{5}{c}{}
\end{tabular}

Table T2. X-ray diffraction analyses results for core samples $(<2 \mu \mathrm{m}$ size fraction), Site C0011. This file is available in .csv format.

Table T3. X-ray diffraction analyses results for core samples $(<2 \mu \mathrm{m}$ size fraction), Site C0012. This file is available in .csv format. 